\title{
CARA KERJA ILMU PENGETAHUAN DAN SIKAP KRITIS TERHADAP INFORMASI DALAM AJARAN ISLAM
}

\author{
Oleh: Amir Syamsudin
}

\begin{abstract}
Abstrak
Islam menganjurkan kepada para pemeluknya untuk bertindak adil. Salah satu indikasi keadilan dalam tindakan ialah membuat keputusan berdasarkan informasi yang benar dan akurat. Untuk mendapatkan akurasi informasi diperlukan tindak penelitian. Penelitian merupakan poros sekaligus proses menyusun ilmu pengetahuan yang muatan informasinya benar dan akurat. Sepanjang ilmu pengetahuan itu diartikan sebagai cara yang rasional dan empiris untuk mempelajari gejala alamiah yang terdapat pada diri manusia dan di luar diri manusia, maka tidak ada satu pernyataan ayat maupun hadis pun yang menentang apalagi mengharamkan aktivitas keilmuan. Realitas adalah segala sesuatu yang diciptakan Tuhan, baik realitas kongkrit maupun realitas ghaib. Realitas kongkrit terdiri dari benda-benda mati, tumbuhan, hewan, manusia, dan benda-benda angkasa. Realitas ghaib meliputi setiap bentuk pewahyuan dari Tuhan kepada orang-orang yang terpilih (Nabi/ Rasul), baik Nabi yang tercantum dalam kitab suci maupun tidak. Realitas kongkrit dapat dibaca oleh pengalaman inderawi maupun akal budi, sedangkan realitas ghaib hanya dapat dikenali oleh manusia setelah pengalaman inderawi dan imajinasi akal budinya mencapai titik batas kemampuannya.
\end{abstract}

Kata Kunci: Cara kerja Ilmu Pengetahuan, Sikap Kritis, dan Ajaran Islam.

\section{Pendahuluan}

Tema Islam bersejajar dengan ilmu pengetahuan modern seolah-olah berasumsi bahwa Islam berseberangan dengan ilmu pengetahuan. Makna berseberangan tidak selalu berarti bertentangan. Islam sebagai sebuah agama diwahyukan pada awal abad ke-7 Masehi, sedangkan ilmu pengetahuan modern sebagai sebuah tafsir atas kenyataan alamiah baru muncul di penghujung abad ke16 Masehi. Tantangan zaman yang melatarbelakangi kemunculan keduanya sangat jauh berbeda, meskipun secara historis yang disebut kedua merupakan kelanjutan dari yang disebut pertama. Dengan demikian, jikapun ada pertentangan antara keduanya, maka pertentangan tersebut terletak pada dan disebabkan oleh perbedaan zaman antara keduanya.

Islam yang menyejarah dalam ruang-waktu semenjak awal abad 7 Masehi sampai awal abad 21 Masehi ini mengalami perjalanan pasang-surut seperti umumnya makhluk hidup. Para sejarawan mencatat pasang-surut tersebut ke dalam tiga periode (Harun Nasution,1991:12-14). 
Pertama yang mereka sebut dengan periode Klasik (650-1250). Ciri umum zaman ini, secara politis/geografis wilayah kekuasaan Islam meluas ke Spanyol di Barat serta daratan China di Timur, dan secara intelektual wacana keilmuan yang bersumber dari penafsiran terhadap al-Qur'an dan Hadis maupun pembacaan terhadap gejala alamiah mencapai klimaks.

Kedua, periode pertengahan (1250-1800). Ciri umum zaman ini, secara politis terjadi disintegrasi dalam wilayah kekuasaan Islam dan secara intelektual mengalami kemunduran: pena diganti senjata, otak diganti otot, buku menjadi barang mewah dan pedang menjadi barang murah.

Ketiga, periode modern (1800-sekarang). Ciri umum zaman ini, secara politis wilayah kekuasaan Islam dirampas dan dijajah oleh orang asing dan secara intelektual terpesona oleh kemajuan ilmu pengetahuan dan teknologi yang digunakan oleh orang asing yang menjadi tuan di rumahnya sendiri.

Umat Islam yang terpesona oleh ilmu pengetahuan modern tersebut menurut Nasim Butt (1996:60-64) memberikan reaksi yang beragam. Tetapi, secara garis besar ada tiga kelompok pemikiran muslim mengenai ilmu pengetahuan modern.

Pertama, sekelompok muslim yang menolak ilmu pengetahuan yang tidak bersumber dari al-Qur'an dan Hadis. Bagi mereka hanya kedua sumber Islam itulah yang layak dan sah sebagai sumber ilmu pengetahuan. Jikalau ada ilmu pengetahuan yang bersumber dari selain al-Qur'an/Hadis seperti ilmu pengetahuan modern, maka status ilmu pengetahuan tersebut fardu kifayah; hanya sebagian kecil orang saja boleh mempelajarinya. Sedangkan ilmu pengetahuan yang harus dipelajari oleh setiap orang muslim (fardu 'ain), tua ataupun muda, pria maupun wanita, ialah wacana keilmuan diseputar kedua sumber Islam tersebut.

Kedua, sekelompok muslim yang berpandangan bahwa ilmu pengetahuan modern perlu di"islam"kan. Suka atau tidak-suka, ilmu pengetahuan modern lahir dari rahim filsafat Yunani (6 Sebelum Masehi) yang dibesarkan oleh gerakan Renaissance (16 M), Reformasi (17 M), dan Pencerahan (18 M) di Eropa Barat (Sartono Kartodirdjo, 1986:36) yang dengan lugas/tegas menyatakan diri tidak bersumber dari ajaran keesaan Tuhan (Tauhid). Islamisasi itu perlu karena landasan filosofis ilmu pengetahuan modern tidak berporos pada ajaran Tauhid. Padahal ajaran Tauhid tersebut merupakan tolok-ukur keabsahan perbuatan seorang muslim, 
sekaligus juga menjadi titik pijak bagi setiap perbuatannya, termasuk dalam aktivitas keilmuan. Oleh karena itu islamisasi merupakan solusi yang tidak bisa dihindarkan.

Ketiga, sekelompok muslim yang berasumsi bahwa ilmu pengetahuan modern itu universal, bebas nilai, dan lintas-budaya sehingga ia dapat dicangkokkan pada sistem keagamaan manapun, termasuk agama Islam. Tugas mendesak itu bukan islamisasi ilmu pengetahuan modern, melainkan upaya keras merubah cara berfikir yang semata-mata literal menjadi liberal sesuai dengan semangat ilmiah dari ilmu pengetahuan modern. Al-Qur'an dan Hadis tidak lagi harus dibaca secara tektual tetapi dapat dimengerti secara kontekstual. Ringkasnya ajaran Islam hanya akan diterima oleh manusia modern, jika dan hanya jika ajaran tersebut cocok dengan kosakata ilmu pengetahuan modern.

Dari gambaran ringkas di atas dapat dipetik beberapa butir pokok masalah untuk didiskusikan dalam tulisan ini. Pertama, bagaimana Islam memandang aktivitas keilmuan untuk mendapatkan pengetahuan, kedua apa itu pengetahuan, ketiga dari mana pengetahuan itu berasal, keempat bagaimana jenis-jenis pengetahuan yang mungkin diperoleh manusia, kelima bagaimana cara/metode menyusun pengetahuan, dan keenam simpulan yang menegaskan tentang pengetahuan sebagai produk sekaligus proses berfikir dalam perspektif norma Islam.

\section{Aktivitas Keilmuan Menurut Islam}

Keseluruhan ajaran Islam sebaiknya dipandang sebagai fakta historis yang mesti dipahami menurut ukuran ruang-waktu dan batas kemampuan manusia dalam memahaminya ketimbang sebagai peristiwa pewahyuan yang hanya terjadi dalam kurun waktu 22 tahun masa kenabian Muhammad saw. (610-632 M) semata.

Penegasan sudut pandang ini penting untuk menghindari pandangan dikotomis bahwa ajaran Islam lebih tinggi mutu informasinya dari ilmu pengetahuan karena ia bersumber dari Tuhan. Sedangkan ilmu pengetahuan bersumber dari realitas ruang-waktu yang dibaca oleh panca indera manusia.

Sepanjang ilmu pengetahuan itu diartikan sebagai cara yang rasional dan empiris untuk mempelajari gejala alamiah yang terdapat pada diri manusia dan di luar diri manusia (Nasim Butt, 1996:69), maka tidak ada satu pernyataan ayat maupun hadis yang menentang apalagi mengharamkan aktivitas keilmuan. Bahkan sebaliknya ajaran Islam mengajarkan sikap kritis pada setiap jenis informasi yang 
dilihat, didengar, dihirup, diraba, maupun dirasa oleh manusia. Sebagai contoh QS. Al-Hujurat (49) :6 yang isinya meminta kita supaya senantiasa berhati-hati dalam menginternalisasi (mengunyah) setiap informasi. Kewaspadaan ini dituntut supaya kita tidak berbuat zalim (anarkı) karena percaya pada informasi yang salah dan berkeputusan berdasarkan makna yang dikandungnya.

Dengan demikian ajaran Islam memberi teladan pada para pemeluknya untuk memiliki sikap kritis terhadap dirinya sendiri maupun terhadap objek lain di luar dirinya dan bersedia mempertanggungjawabkan semua pernyataan dan perbuatan yang diciptakannya. Hal seperti ini merupakan semangat ilmiah yang tulen dan sangat menjunjung tinggi nilai sportifitas dalam berkarya.

Semangat ilmiah yang ditawarkan ajaran Islam bukan semata-mata macan kertas, tetapi ia diwujudkan dalam setiap ritual-keagamaan Islam. Ciri khas ajaran Islam yang menekankan iman dan amal shaleh ini nampak jelas dalam poses mendidik manusia supaya menjadi makhluk ilmiah. Sebagai ilustrasinya kita ambil praktik ritual ibadah shalat.

Dalam setiap perbuatan shalat mesti membaca ummul kitab (QS. Al-Fatihah (1): 1-7). Dari ketujuh ayat yang terkandung di dalamnya terdapat satu ayat yang berisi permohonan kita kepada Allah supaya ditunjukkan pada jalan yang lurus. Yang dimaksud dengan jalan lurus ialah jalan kebenaran. Untuk mencapai kebenaran dipersyaratkan supaya kita mengurung keinginan subyektif dan egoisme kita sendiri disamping diharuskan memperkuat kemauan untuk mendapatkannya. Permohonan tersebut merupakan titik pijak perjuangan panjang manusia untuk melepaskan diri dari kepentingan subyektifnya dan mengikatkan diri pada kebenaran objektif yang ditemukannya. Perjuangan ini tidak akan sampai di tujuan kecuali Allah memberi petunjuk ke arah jalan yang benar, karena Tuhanlah pemilik mutlak atas kebenaran, sedangkan manusia hanya menangkap "percikan"nya saja (Nurcholis Madjid, 1995: 397). Ringkasnya, dalam ritual shalat terdapat proses pendidikan sepanjang hayat manusia; yaitu mendidik manusia menjadi makhluk yang beramal ilmiah dan berilmu amaliah.

\section{Pengertian Pengetahuan}

Cara mudah untuk memahami arti pengetahuan ialah dengan cara membandingkan antara pengetahuan dengan keyakinan. Keduanya berbeda 
meskipun mempunyai hubungan yang erat satu sama lain. Persamaan antara keduanya terletak pada sama-sama persepsi orang tentang sesuatu objek. Perbedaannya, kalau pengetahuan menyangkut persepsi orang tentang objek yang dapat dibuktikan keberadaannya, sedangkan keyakinan berhubungan dengan persepsi orang tentang objek sebelum dibuktikan keberadaannya atau setelah proses pembuktian namun tidak ada satu faktapun yang mendukung akan keberbadaan objek tersebut.

Sebagai ilustrasi, saya tahu ada orang yang masuk ke kamar saya ketika saya di kampus. Pernyataan ini disebut pengetahuan apabila didukung oleh bukti-bukti, misalnya kunci pintu kamar menjadi rusak, pakaian di lemari menjadi semerawut, ada bekas pegangan tangan pada buku-buku, keysboard, dan CPU komputer, sejumlah barang berharga hilang dari tempat penyimpanannya dan peristiwanya terjadi antara pagi sampai siang hari. Namun apabila tidak ada satu buktipun yang mendukung pernyataan di atas, maka pernyataan tersebut jatuh menjadi keyakinan.

Demikian pula kalau kita menuduh seseorang melakukan tindakan a-susila tanpa didukung oleh bukti-bukti yang memperkuat tuduhan tersebut, maka tuduhan itu bukan pengetahuan melainkan hanya keyakinan dan dalam istilah agama disebut fitnah yang sifatnya lebih kejam dari pembunuhan. Ringkasnya setiap keyakinan adalah pengetahuan sebaliknya tidak setiap pengetahuan adalah keyakinan karena hanya keyakinan yang didukung oleh bukti-bukti sajalah yang disebut pengetahuan.

Pengetahuan selalu mengacu pada kenyataan dan bukan pada khayalan. Pengetahuan hanya sah disebut pengetahuan apabila memenuhi dua syarat:

1. Pernyataan harus diambil dari dan cocok dengan kenyataan.

2. Orang yang membuat pernyataan harus sadar bahwa pernyataan yang dibuatnya mengacu pada kenyataan.

Berdasarkan dua syarat sahnya pengetahuan di atas, maka pengetahuan bisa beragam menurut polanya masing-masing (A. Sony Keraf \& Mikhael Dua, 2001: 3042), setidaknya ada empat macam pola pengetahuan:

Pertama, "Tahu Bahwa". Pengetahuan jenis ini mengacu pada akurasi informasi. Saya tahu bahwa sejak saya kecil sampai sekarang dewasa, burung pipit membangun sarangnya selalu dalam bentuk dan ukuran yang sama.

Kedua, "Tahu Bagaimana". Pengetahuan semacam ini berhubungan dengan cara mengoperasikan suatu alat atau menggunakan suatu keahlian. Kalau kita 
diminta menjelaskan bagaimana cara mengoperasikan MS Word, kemudian penjelasan itu menjadikan orang lain mampu melakukan hal yang sama dengan penjelasan kita, maka kita berhak disebut memiliki pengetahuan teknis tentang MS Word.

Ketiga, "Tahu Akan". Pengetahuan model ini bertumpu pada pengenalan pribadi terhadap objek yang ingin diketahuinya. Ciri umum pengetahuan ini (1) mutu objektivitasnya sangat tinggi karena mengenali objek dari aspek lahir dan batinnya secara langsung. Namun unsur subjektifnya pun cukup kuat, karena objek dilihat, dirasakan, dan dikenali dalam kacamata sejarah pribadinya, seluruh cara pandangnya, seluruh minatnya dan seluruh sikap batinnya; (2) Orang yang mengenali objeknya secara langsung mampu memberi penilaian yang akurat terhadap objek tersebut; dan (3) berkaitan dengan objek khusus, misalnya gejala agama yang dikenal secara langsung dan bersifat personal.

Keempat, "Tahu Mengapa". Pengetahuan ini bersesuaian dengan "Tahu Bahwa" hanya saja lebih mendalam. Kalau yang disebut terakhir bersifat deskriptif (pemaparan tentang objek), maka yang disebut pertama bersifat preskriptif (penjelasan tentang objek). Dengan demikian "Tahu Mengapa" selalu ingin mencari tahu apa yang dibalik informasi yang dipaparkan "Tahu Bahwa".

Adapun sumber keempat pengetahuan tersebut di atas mengacu pada alatalat iderawi dan akal budi yang dimiliki manusia.

\section{Sumber Pengetahuan}

Sumber pengetahuan adalah asal-usul dari mana pengetahuan itu diperoleh. Untuk memahami asal pengetahuan perlu di lihat dari dua aspek. Pertama dari aspek manusia yang memproduksi pengetahuan dan kedua dari aspek realitas yang menjadi bahan mentah pengetahuan.

Perdebatan antara kelompok orang yang menyatakan bahwa sumber pengetahuan adalah pengalaman inderawi dengan kelompok orang yang meyakini bahwa sumber pengetahuan adalah akal budi sudah berlangsung, lebih kurang, 2600 tahun lamanya (Harun Hadiwiyono, 1980: Jilid I \& II). Masing-masing kelompok bersikukuh dengan pandangan metafisiknya. Kelompok pertama dipelopori oleh Aristoteles (384-322 SM), John Locke (1632-1704), dan David Hume (1711- 
1776), sedangkan kelompok kedua disponsori oleh Plato (427-347 SM), Rene Descartes (1596-1650), dan Leibniz (1646-1716).

Pergumulan intelektual tersebut disintesakan oleh Immanuel Kant (17241804). Ia sependapat dengan kelompok Empirisis bahwa tanpa pengalaman inderawi tidak mungkin lahir pengetahuan. Ia juga sependapat dengan kelompok Rasionalis bahwa pengalaman inderawi semata, tanpa ditata oleh unsur apriori dari pikiran manusia, yaitu kesadaran akan ruang-waktu dan hubungan sebab-akibat, maka pengetahuan manusia tidak dapat dimengerti. Oleh karena itu, ia berkesimpulan bahwa pengetahuan manusia terdiri dari campuran antara unsur akal budi dan unsur pengalaman inderawi. Pengalaman inderawi sebagai objek material (bahan mentah) pengetahuan, sedangkan akal budi sebagai objek formal (sudut pandang) pengetahuan. Ringkasnya, sumber pengetahuan dari aspek manusia yang memproduksi pengetahuan terdiri dari unsur pengalaman inderawi dan unsur akal budi (A. Sony Keraf \& Mikhael Dua, 2001: 43-64).

Realitas adalah segala sesuatu yang diciptakan Tuhan, baik realitas kongkrit maupun realitas ghaib (al-Attas, 1995: 17-70 dan Daud, 1997). Realitas kongkrit terdiri dari benda-benda mati, tumbuhan, hewan, manusia, dan benda-benda angkasa. Realitas ghaib meliputi setiap bentuk pewahyuan dari Tuhan kepada orangorang yang terpilih (Nabi/Rasul), baik Nabi yang tercantum dalam kitab suci maupun tidak. Realitas kongkrit dapat dibaca oleh pengalaman inderawi maupun akal budi, sedangkan realitas ghaib hanya dapat dikenali oleh manusia setelah pengalaman inderawi dan imajinasi akal budinya mencapai titik batas kemampuannya. Misalnya, proses Nabi Ibrahim a.s. mencari Tuhan (QS. al-An'am (6): 74-83). Konon kabarnya sang Nabi ini ingin menemukan Tuhan yang bersifat abadi; Tidak mengalami proses perubahan dan terhindar dari kemusnahan. Pada saat malam sudah gelap, dia melihat-lihat ke angkasa dan menemukan banyak benda angkasa yang gemerlapan. Salah satu benda langit yang menarik perhatiannya adalah bintang. Setelah cukup puas mengamati bintang, dia membuat keputusan "Inilah Tuhanku"; Ia lebih cemerlang dibanding benda angkasa lainnya. Namun ketika Ibrahim terbangun menjelang pagi, bintang itu lenyap dari pandangannya. Dia pun berkesimpulan bahwa bintang itu bukan Tuhanku, karena aku sangat tidak suka pada sesuatu yang hilang. 
Keesokan harinya, ketika malam mulai gelap dan terbitlah bulan di ufuk Timur, maka dia pun meneguhkan hatinya bahwa inilah "Tuhanku"; Ia lebih terang cahayanya dan ukurannya lebih besar dibanding bintang. Tetapi lagi-lagi dia harus kecewa karena pada saat terjaga dari tidurnya bulan itu sudah terbenam. Kemudian dia pun berkeyakinan bahwa bulan itu bukan Tuhanku dan seandainya Tuhan yang "asli" tidak memberi petunjuk, maka aku akan termasuk golongan orang-orang yang sesat.

Demikianlah di saat Ibrahim kecewa berat terhadap dua benda langit yang dianggapnya Tuhan tersebut, dia melihat matahari terbit dan dia pun bergembira hati bahwa inilah "Tuhanku" yang sebenarnya; Ia lebih kemilau dan ukurannya lebih besar dari dua "tuhanku" sebelumnya. Tetapi tatkala matahari terbenam di sore hari, dia pun cepat-cepat mengoreksi keyakinan yang sudah dipancangkannya dan menegaskan bahwa matahari itu bukan Tuhanku. Oleh karena itu, akhirnya Ibrahim berikrar bahwa aku hanya akan tunduk patuh pada Tuhan yang menciptakan langit dan bumi dengan cenderung pada agama yang benar dan aku bukanlah golongan orang-orang yang menyekutukan Tuhan.

Dengan demikian manusia yang dibekali panca-indera dan akal budi dapat membaca realitas kongkrit dan ketika pembacaan atas realitas kongkrit tersebut mencapai titik puncak batas-batas kemampuannya, maka saat itulah terbuka pintu untuk pembacaan terhadap sebagian dari realitas ghaib. Akal budi Ibrahim menyatakan bahwa Tuhan itu idealnya terhindar dari sifat muncul-tenggelam dan pengalaman inderawi Ibrahim pun memberikan bukti bahwa realitas kongkrit tidak bisa lepas dari sifat lahir-musnah.

Realitas meta-inderawi merupakan jembatan penghubung antara kesenjangan tuntutan akal budi dan bukti yang disodorkan pengalaman inderawi. Realitas metainderawi dalam istilah agama disebut dengan realitas ghaib. Persoalan yang tersisa adalah bagaimana cara mengetahui realitas kongkrit sebagai tangga untuk mengenali realitas ghaib? Bagian berikut ini akan membicarakan cara menyusun pengetahuan dari realitas kongkrit.

\section{Cara Menyusun Ilmu Pengetahuan}

Ilmu pengetahuan adalah sekumpulan pengetahuan yang disusun secara sistematis sebagai jawaban atas permasalahan yang diteliti secara logis. Dari definisi 
di atas ada tiga hal yang menjadi unsur kegiatan keilmuan, yaitu (1) perumusan masalah, (2) proses penelitian atas masalah, dan (3) perumusan jawaban atas masalah.

Cara menyusun ilmu pengetahuan harus beranjak dari permasalahan. Setiap masalah perlu penjelasan. Setiap penjelasan selalu berdimensi ganda: Sebagai solusi/jawaban atas masalah sekaligus sebagai titik tolak untuk bertanya. Setiap pertanyaan mengandaikan beberapa dimensi, yaitu (1) tidak mengetahui sesuatu, (2) memiliki keinginan kuat untuk mengetahuinya, dan (3) usaha untuk menemukan kebenaran. Ringkasnya dalam menyusun ilmu pengetahuan, di awali dengan pertanyaan/masalah, di akhiri dengan jawaban/solusi, dan dijembatani aktivitas penelitian diantara keduanya. Adapun model aktivitas penalaran dalam penelitian diantaranya abduksi, deduksi dan induksi.

Abduksi ialah suatu proses penyimpulan dari suatu kasus tertentu. Abduksi terdiri dari tiga hal, yaitu (1) pernyataan tentang suatu hukum, (2) pernyataan tentang suatu kasus, dan (3) pernyataan tentang kesimpulan (A. Sony Keraf \& Mikhael Dua, 2001:88-96). Contohnya "Shalat itu mencegah perbuatan keji" (hukum), "shalatnya rajin tetapi korupsinya jalan terus" (kasus), maka jawaban atas pertanyaan mengapa terjadi kesenjangan antara norma ideal dengan norma aktual, dapat dijawab dengan beberapa kemungkinan, diantaranya atau (1) shalatnya tidak khusyu', atau (2) shalatnya untuk memenangkan Pemilu, atau (3) shalatnya untuk memenuhi azas formalitas, atau (4) shalatnya sebagai keterampilan yang dibiasakannya semenjak usia sekolah dasar, atau (5) shalatnya untuk mendapatkan pahala sebanyak-banyaknya dengan biaya yang semurah-murahnya (kapitalisme ibadah personal), atau (6) kemungkinan jawaban lainnya. Kelima jawaban di atas merupakan pernyataan tentang kesimpulan. Abduksi berfungsi menawarkan suatu dugaan yang dapat memberikan penjelasan terhadap fakta-fakta. Ciri-ciri abduksi diantaranya (1) memberikan satu penjelasan yang mungkin, (2) memberi penjelasan terhadap fakta-fakta lain yang belum dijelaskan atau bahkan tidak dapat diobservasi secara langsung, (3) dugaan abduktif dibentuk oleh imajinasi, bukan oleh penalaran kritis karena ia tidak muncul dari proses logis yang ketat, tetapi dari "kilatan pengertian" di bawah penalaran kritis, (4) berusaha menangkap keaslian realitas, dan (5) abduksi yang berhasil mempersyaratkan keterlibatan total dari imajinasi yang bebas. 
Deduksi ialah usaha untuk menyingkapkan konsekuensi-konsekuensi dari penjelasan yang bersifat dugaan (A. Sony Keraf \& Mikhael Dua, 2001:97-98). Contohnya "orang yang sedang berpuasa memiliki ciri-ciri, diantaranya (1) mulutnya kering, (2) nafasnya sedikit berbau, dan (3) mukanya agak pucat" (pernyataan umum); Pak Soma sedang berpuasa (pernyataan khusus); Karenanya/seharusnya Pak Soma memiliki ciri-ciri di atas (pernyataan konsekuensi). Tugas deduksi ialah mengekplisitkan pernyataan yang implisit dengan cara mencocokkan dugaan tersebut dengan kenyataan. Namun pencocokkannya tersebut hanya terjadi di atas kertas karena sang peneliti harus mencari jawabannya sendiri dari realitas. Tugas inilah yang dilakukan induksi.

Induksi ialah cara kerja menyusun ilmu pengetahuan yang berawal dari sejumlah pernyataan kasuistik dan berakhir dengan menarik kesimpulan/pernyataan umum (A. Sony Keraf \& Mikhael Dua, 2001:99-117). Prinsip penyimpulan dari kasus ke umum tersebut bertumpu pada aspek kesamaan, keterkaitan, dan keajegan peristiwa faktual tersebut. Ciri umum dari induksi adalah bahwa pernyataan induktif selalu tidak lengkap. Misalnya,

Ahmad yang rajin shalat selalu bertindak jujur (kasus 1).

Budi yang suka puasa Senin-Kamis senantiasa bertindak jujur (kasus 2).

Rais yang suka pergi haji tiap tahun kerap bertindak jujur (kasus 3 ).

Hamid yang suka zakat acapkali bertindak jujur (kasus 4).

Alex yang suka menolong orang susah terbiasa bertindak jujur (kasus 5).

Kesimpulannya bahwa orang yang taat beragama akan dapat dipercaya.

Kesimpulan yang merupakan dugaan ini, kalau ternyata kemudian terbukti benar, muatan informasinya bersifat terbatas dan tidak pernah lengkap karena hanya menyangkut beberapa fakta saja, yang diasumsikan mencakup seluruh fakta lain yang sejenis. Demikian pula kebenarannya bersifat sementara karena bisa saja ada fakta lain yang menyangkal isi kesimpulan di atas.

Adapun langkah-langkah penalaran induktif terdiri dari (1) situasi masalah, (2) pengajuan dugaan, (3) penelitian lapangan, dan (4) pengujian dugaan.

Pertama, situasi masalah. Maksudnya ada masalah tertentu yang sulit dijawab oleh kumpulan pengetahuan yang dimiliki sehingga mendorong orang untuk melakukan penelitian guna mencari jawaban atas masalah tersebut. Kedua, pengajuan dugaan. Artinya "dugaan sementara" dibuat berdasarkan akal sehat, dugaan murni, spekulasi, imajinasi, maupun asumsi tertentu yang diinspirasi oleh pengetahuan yang dimiliki, bahkan kalau dianggap perlu melakukan studi kepustakaan secara 
intensif. Ketiga, penelitian lapangan untuk mengamati dan mengumpulkan fakta sebanyak mungkin yang dibimbing oleh dugaan tersebut. Dugaan ini berfungsi sebagai alat bantu penelitian yang tujuannya untuk menjawab masalah tersebut berdasarkan dugaan yang diajukan. Keempat, pengujian dugaan. Dalam langkah terakhir ini "dugaan sementara" di uji berdasarkan fakta yang sudah terkumpul. Kalau dugaan sementara tersebut didukung oleh fakta terkumpul, maka dugaan tersebut berubah statusnya menjadi "teori", tetapi kalau terjadi sebaliknya, maka dugaan tersebut gugur dan harus dibuat dugaan lain sebagai gantinya. Jika dugaan tersebut di dukung oleh fakta, maka kebenaran isi fakta tersebut harus diuji dengan cara menurunkan perkiraan/konsekuensi dari teori baru tersebut di periode waktu yang akan datang. Apabila perkiraan-perkiraan tersebut didukung oleh fakta-fakta yang terkini ditemukan, maka semakin kokohlah teori baru tersebut. Tetapi apabila teori baru tersebut disangkal oleh fakta-fakta aktual, maka teori baru itu harus diteliti ulang, dan demikianlah seterusnya sampai usia peniliti itu habis ditelan zaman.

\section{Simpulan}

Islam menganjurkan kepada para pemeluknya untuk bertindak adil. Salah satu indikasi keadilan dalam tindakan ialah membuat keputusan berdasarkan informasi yang benar dan akurat. Untuk mendapatkan akurasi informasi diperlukan tindak penelitian. Penelitian merupakan poros sekaligus proses menyusun ilmu pengetahuan yang muatan informasinya benar dan akurat. Ringkasnya, secara doktrinal, Islam tidak bertentangan dengan cara kerja ilmu pengetahuan.

Demikian pula sumber pengetahuan menurut ajaran Islam tidak tercerai berai menjadi akal budi lawan pengalaman inderawi, atau kenyataan kongkrit berlawanan dengan kenyataan ghaib, karena baik akal budi/pengalaman inderawi maupun kenyataan kongkrit/kenyataan ghaib, keduanya merupakan sumber pengetahuan yang sah sekaligus bagian terkecil dari keseluruhan ciptaan Tuhan.

Cara menyusun ilmu pengetahuan sepenuhnya hasil "ijtihad"/daya kreasi manusia. Islam hanya berkepentingan dengan perilaku etis manusia ketika mereka mau menggunakan hasil ijtihad mereka tersebut. Al-Qur'an menyatakan "telah jelas dan beda antara jalan lurus dengan jalan sesat", dan manusia dihalalkan untuk memilah dan memilih; Apakah ilmu pengetahuan yang dimilikinya akan digunakan 
untuk memakmurkan bumi atau menghancurkannya; Apakah aktivitas penelitian yang dilakukannya ditujukan untuk memberikan kesejahteraan pada sebanyak mungkin manusia atau justeru untuk menyengsarakannya. Nestapa manusia berawal dari kebodohannya dan berakhir dengan menyalahgunakan kepintarannya. 


\section{Bahan Acuan}

Alouis Sonny Keraf \& Mikhael Dua. 2001. IImu Pengetahuan: Sebuah Tinjauan Filosofis. Yogyakarta: Kanisius.

DEPAG RI. 1992. Al-Qur'an dan Terjemahannya. Semarang: PT Inti Tanjung Mas.

Harun Hadiwijono. 1980. Sari Sejarah Filsafat Barat I \& II. Yogyakarta: Kanisius.

Harun Nasution. 1991. Pembaharuan dalam Islam. Jakarta: Bulan Bintang.

Nasim Butt. 1996. Sains dan Masyarakat Islam, terj. Masdar Hilmy. Bandung: Pustaka Hidayah.

Nurcholis Madjid. "Shalat" dalam Budhy Munawar-Rachman (ed.). 1995. Kontekstualisasi Doktrin Islam dalam Sejarah. Jakarta: Paramadina.

Sartono Kartodirdjo. 1986. Ungkapan-ungkapan Filsafat Sejarah Barat \& Timur: Penjelasan Berdasarkan Kesadaran Sejarah, terj. M. Pusposaputro. Jakarta: Gramedia.

Syed Muhammad Naquib al-Attas. 1995. Islam dan Filsafat Sains, terj. Saeful Muzani. Bandung: Mizan.

Wan Mohammad Nor Wan Daud. 1997. Konsep Pengetahuan dalam Islam, terj. Munir. Bandung: Pustaka.

\section{Biodata Penulis}

Amir Syamsudin lahir di Ciamis, Jawa Barat. Ia menempuh pendidikan dasar sampai menengah di Pondok Pesantren Darussalam, Ciamis - Jawa Barat. Kemudian pada 1991, ia hijrah ke Yogyakarta untuk menimba ilmu agama pada IAIN Sunan Kalijaga Yogyakarta. Maret 1997 menyelesaikan jenjang S-1 dalam bidang kajian Aqidah dan Filsafat dan Agustus 1999 menyelesaikan jenjang S-2 dalam program studi Agama dan Filsafat, Konsentrasi Filsafat Islam. Karya tulis yang pernah dibuat antara lain: Hubungan Subyek-Obyek menurut Cornelis Anthonie van Peursen dalam buku Strategi Kebudayaan yang diajukan kepada Fakultas Ushuluddin sebagai skripsi dan Teori Pengetahuan Ibn Thufayl \& Rene Descartes: Perbandingan tentang Teori Kebenaran yang diajukan kepada Program Pascasarjana IAIN Sunan Kalijaga sebagai thesis. Mulai tanggal 21 Juli 2008 mendapatkan kesempatan tugas belajar dari Departemen Agama RI pada Program Studi Penelitian dan Evaluasi Pendidikan Stratum 3 (PEP S-3) Universitas Negeri Yogyakarta sampai dengan Agustus 2011. Ia mulai bekerja sebagai staf pengajar Mata Kuliah Pengembangan Kepribadian (MPK)-Pendidikan Agama Islam pada Universitas Negeri Yogyakarta sejak Agustus 1999 sampai sekarang. 